\title{
The implementation of distance learning during the pandemic: the experience of the Timiryazev Academy
}

\author{
Aleksandr Borisovich Orishev ${ }^{1}$, Azer Agabala ogly Mamedov, Sergei Leonidovich Grigorev, \\ Dmitrii Vyacheslavovich Kotusov, and Kseniya Yurevna Donskikh \\ Russian State Agrarian University - Moscow Agricultural Academy named after K.A. Timiryazev, \\ Department of History, Moscow, Russia
}

\begin{abstract}
For the modern higher education system, it is difficult to find a more relevant topic than distance learning. Having tested the distance format in the spring of 2020, when strict self-isolation measures were introduced by the decision of the city authorities, higher educational institutions in Moscow switched to this format again in the fall of 2020, in connection with the onset of the second wave of the pandemic. Considering that subsequent waves of the spread of COVID-19 or other viruses are possible, Russian higher educational institutions must be ready to take on new challenges, which makes improving the distance learning system in each specific educational institution an extremely important task in planning and organizing the educational process. The purpose of the study: to share the experience of the Timiryazev Academy on the implementation of distance learning during the pandemic. The object of the research is distance learning. The subject of the research is the implementation of distance learning at the Timiryazev Academy in the 2019-2020 and 2020-2021 academic years. The research methods are content analysis of the official website of the Timiryazev Academy and other Internet resources, as well as the sociological survey of students of the Timiryazev Academy. The article shows the main problems that the academy faced when implementing distance learning: selection of high-quality content, psychological preparation of teachers, establishment of operational communication, as well as the provision of students with means of communication. The main scientific result: it is shown that the key to successfully overcoming the difficulties and solving the problems caused by the pandemic was the course for the consistent digitalization of the educational process, which began to be performed at the Timiryazev Academy even before the pandemic started.
\end{abstract}

Keywords: COVID-19, distance learning, educational process

\section{Introduction}

\footnotetext{
${ }^{1}$ Corresponding author: orishev71@mail.ru
} 
The modern higher education system faced a challenge in the face of the COVID-19 pandemic, when higher educational institutions, obeying the decisions of the heads of the constituent entities of the Russian Federation, were forced to transfer their students to distance learning. And if in the spring of 2020 this transition was a shock for higher educational institutions, then in the fall of 2020, during the second wave of the pandemic, it was assumed that distance learning had reached a higher quality level, and all the shortcomings and drawbacks that had appeared earlier were eliminated. The novelty of the study lies in the fact that the scientific literature has not yet attempted to compare the implementation of distance learning at different stages of the pandemic, which can be done using the example of the Timiryazev Academy. Therefore, the purpose of this study is to share with the scientific community the experience of the Timiryazev Academy on implementing distance learning during the pandemic. To achieve this goal, it was necessary to solve the following tasks: describe the problems that the academy faced during the spread of COVID-19, show ways to solve these problems, and analyze the literature on the research topic.

\section{Methods}

To achieve this goal and solve the research problems, the methods developed by modern science were used. Through content analysis, the official website of the Timiryazev Academy, the learning management system (LMS) Moodle, corporate e-mail materials, and social networks were examined. With the help of the sociological survey, the reflection of students on distance learning was investigated.

\section{$3 \quad$ Results}

It is not a secret that for many Russian higher educational institutions, the transition to distance learning came as an absolute surprise, when students and teachers were not ready to study and work in the new conditions. For the Timiryazev Academy, on the contrary, the transition did not come as an unpleasant surprise due to the fact that this university, even before the onset of the pandemic, took a course towards digitalization of the educational process. In 2019, the "Electronic information and educational environment of the University" [1] was created at the Russian State Agrarian University - Moscow Agricultural Academy (RSAU-MAA). Moreover, all teachers during January-February 2020 completed the relevant advanced training courses in the amount of 72 hours.

The transition to distance learning in the spring of 2020 took place gradually. At the first stage, the student groups were transferred to this form of training, in which infected students were found. And only on March 18, 2020, in connection with the transfer of all Moscow higher educational institutions to distance learning, this transition became total: students of all forms of education began to study remotely: intramural, intra-extramural and extramural.

The main platform for distance learning was the "Electronic information and educational environment of the University" located at portal.timacad.ru. The training was also conducted using special programs for providing distance learning. The format of the lesson was determined by each teacher independently.

It was assumed that lectures and workshops will be conducted in the format of a webinar. For this, teachers were recommended to use three services, and for each of them detailed instructions were attached on the official website: Mirapolis, Zoom, and Skype. At the same time, the administration of the university did not insist on this or that service, 
delegating the decision-making on the choice of a specific service to the academic teaching staff.

For operational communication between the teacher and the student, personal accounts were created for each employee and student on the website of the RSAU-MAA (the previously indicated "portal"). Before the beginning of each lesson, the teacher provided all the necessary information: posted a link to the resource via which it was planned to conduct the lesson (Mirapolis, Zoom or Skype). Correspondence between the teacher and students was also established here, since on the portal the organizers posted information about all employees and, if desired, the student could find any teacher. If desired, the teacher could contact the student of interest to him or her. In addition to posting contact information, it was assumed that teachers would create a portfolio on the portal, the components of which would be information on advanced training, indicators of scientific-research, organizational-methodological and educational-methodological work. Moreover, the schedule of training sessions was posted on the portal, as well as a chat for communication was arranged. It was proposed to use a virtual disk as data storage, where teachers could place presentations, small video files, etc. To transfer the necessary information for the lessons, teachers were also offered to use cloud services: GoogleDrive, OneDrive, Dropbox, YandexDisk. The academic library named after N.I. Zheleznov, providing students with its electronic resources, also offered its services.

For operational communication, along with the portal, the LMS Moodle learning management system was used. A corporate mail was created and each employee received a personal address to which it was proposed to send letters to teachers. In addition, the educational and methodological department (EMD) recommended that teachers actively use social networks. It is noted that the forefront here were the teachers of the Department of History, who by the beginning of the epidemic already had vast experience in using social networks in the educational process (Facebook, VKontakte, etc.) [2].

Attention was paid to recording video sessions, for which access to programs was provided: Free Screen Video Recorder - a compact program for recording video from a screen and capturing images, iSpring Free Cam - a free program for recording video from a screen. In addition, the educational and methodological department offered additional electronic online courses that were formed by the Ministry of Science and Higher Education of Russia for the effective organization of the educational process using e-learning and distance learning technologies. It is noted that in the context of the pandemic, this list of online courses was implemented free of charge. The list consisted of 710 titles and covered not only the disciplines of social and humanitarian cycles (English for engineers, Introduction to gender sociology, History, History and methodology of science, History and philosophy of technology, Cultural studies) but also numerous disciplines of specialization (Institutional economics, History of technology survival, Technology commercialization, Laser technology, etc.). In addition, students were given the opportunity to enroll in 722 courses of leading Russian universities through the "Open Education" platform, connect to 1,765 courses and 68 platforms through the "Modern digital educational environment in the Russian Federation" portal.

For operational communication with the administration of the higher educational institution, the students were offered the option "Questions and answers" on the official website of the academy. It also contained detailed answers to the most relevant questions for students: "How do I know in what format the lectures will be held?", "How long will learning using distance learning technology continue?", "Will the transition to distance learning affect the opportunity to switch to the state-funded form of education?" A separate block of questions was devoted to teaching students living in dormitories.

The first two weeks after the start of transferring to distance learning revealed the problems that had to be faced. Most of the teachers and students got used to it and 
established stable interaction. Some teachers even "overdid it", overloading the students with tasks. Then a period of stable work began, in which the EMD strongly recommended that teachers not overload students with a large amount of material, post only what is necessary for high-quality mastering of the current topic (for students wishing to study the topic more deeply, to post additional sources, in the form of references or links); issue assignments to students for the study of the next topic only on the day of the lesson according to the current schedule and demand that the assignment be completed no earlier than the date of the next lesson, while developing assignments (questions, tests, tasks, etc.) strictly on the studied topic and with an acceptable level of difficulty; when conducting lectures or practical classes in the format of a videoconference or webinar, to conduct such a lesson according to the current schedule of classes, while students must be notified in advance; provide the dean's office/directorate with information regarding the activity of students only on the day of the lesson.

The summer of 2020 has become the time of "working on mistakes". If the problem of lack of qualitative content was partly solved by posting author's educational courses on the LMS Moodle platform, then the problem of teachers' unpreparedness for distance learning was solved in a different way. Drastic measures were taken against those who could not adapt to the remote format: labor relations with them were terminated. With others, the problem was solved by conducting internal advanced training courses.

In the fall of 2020, when the second stage of distance learning began, the EMD strengthened its control over the conduct of lectures and seminars: the teacher was charged to post a photo report about the conducted lesson. The report was processed weekly by the staff of the EMD, and information about the quality of the conducted classes was sent to the departments. If desired, any teacher could get acquainted with the photo report of his or her colleagues.

As the monitoring of the quality of the educational process and feedback, the sociological survey was used, during which students were asked to name the advantages and disadvantages of distance learning, as well as to formulate proposals for its improvement. The results of the survey showed that the academy managed to establish distance learning at a high methodological level, and the overwhelming majority of students were able to adapt to the new format (see Table 1).

Table 1. Results of the sociological survey "Distance learning through the eyes of students".

\begin{tabular}{|l|l|c|}
\hline No. & \multicolumn{1}{|c|}{ Assessment of the transition to the distance learning system } & $\mathbf{\%}$ \\
\hline 1 & Quite satisfied with the transition to distance learning & 9.8 \\
\hline 2 & Satisfied rather than dissatisfied & 38 \\
\hline 3 & I do not see any fundamental differences for myself & 19.5 \\
\hline 4 & Rather dissatisfied than satisfied & 23.7 \\
\hline 5 & Strongly against the transition to the remote format & 9 \\
\hline
\end{tabular}

\section{Discussion}

Distance learning in higher educational institutions became the subject of research by Russian scientists more than 10 years ago. The first work dates back to 2006 [3]. Soon, other articles devoted to this problem appeared [4-6]. The works on the study of distance learning in foreign countries were published [7, 8]. However, the publications devoted to the transition to distance learning during the COVID-19 pandemic are of the greatest interest to the authors $[9,10]$. The publications released after the return of Russian students to traditional education in 2021 are also noteworthy $[11,12]$. This article is partly a continuation of these studies. It is suggested to name the works in which the problems 
associated with the transition to distance learning in foreign countries were raised [13, 14, $15,16]$.

\section{Conclusion}

The conducted study allows concluding that distance learning at the Timiryazev Academy during the pandemic was organized at a high scientific and methodological level. The reasons for this were the following: the course taken in advance for the digitalization of the educational process; collaboration with other higher educational institutions - connecting to their educational programs; optimization of the staff - the dismissal of teachers who are not able to adapt to remote work; establishing regular feedback with students - the main consumers of educational services.

\section{References}

1. P.F. Kubrushko, A.Y. Alipichev, E.N. Kozlenkova et al., J. Phys.: Conf. Ser. 1691, 012116 (2020). https://doi.org/10.1088/1742-6596/1691/1/012116

2. A.B. Orishev, A.A. Mamedov, D.V. Kotusov et al., J. Phys.: Conf. Ser. 1691, 01209 (2020). https://doi.org/10.1088/1742-6596/1691/1/012092

3. A.Yu. Netseevskii, Inf. Telecomm. Tech. 1, 61-64 (2006)

4. A.Yu. Kremneva, Prior. Res Areas: Theory to Prac. 1, 95-98 (2012)

5. K.V. Grebeneva, A.V. Grebeneva, E.N. Semenova, Edu. Envir. Today: Devel. Strat. 1(2), 383-385 (2015)

6. G.R. Mullakhmetova, E.P. Molostova, Sci. Edu.: New Age 6(23), 372-375 (2017)

7. V.D. Chukhlomin, ECO, 10(1), 71-79 (2007)

8. S.N. Stepanova, Europ. Sci. 1(33), 71-75 (2018)

9. A.V. Boikova, Int. J. Human. Nat. Sci. 4-2(43), 29-31 (2020)

10. N.B. Kushcheva, Distantsionnoe obuchenie v vuzakh Rossii: tsifrovye tekhnologii v period pandemii [Distance learning in Russian higher educational institutions: digital technologies during the pandemic], in Socio-economic development in the digital society. Proc. IX National Sci. and Prac. Conf. of the Institute of Magistracy with international participation. St. Petersburg State University of Economics. St. Petersburg: St. Petersburg State University of Economics, 84-90 (2020)

11. F.F. Bulatova, N.S. Sakharova, V.V. Tomin, et al., Propositos y representaciones, 9 , e1131 (2021). http://dx.doi.org/10.20511/pyr2021.v9nSPE3.1131

12. O.G. Tavstukha, O.M. Osiyanova, T.V. Chelpachenko, et al., Propositos y representaciones, 9, e1133 (2021). http://dx.doi.org/10.20511/pyr2021.v9nSPE3.1133

13. K.B. Bataineh, M.S. Atoum, L.A. Alsmadi, et al., Edu. Int. J. Inf. Comm. Tech. Edu. 2(17), 138-148 (2021). https://doi.org/10.4018/IJICTE.20210401.oa1

14. A.J. Catalano, B. Torff, K.S. Anderson, Int. J. Inf. and Learn. Tech. 38, 258-270 (2021). https://doi.org/10.1108/IJILT-06-2020-0111

15. E.A. Humphrey, J.R. Wiles, Eco. Evol. P. 2, 11(8), 1-9 (2021). https://doi.org/10.1002/ece3.7303

16. A. Alamer, F. Alharbi, Insights Imaging, 12, 41 (2021). https://doi.org/10.1186/s13244-021-00984-w 